\title{
DETERMINAN OPINI AUDIT GOING CONCERN PADA PERUSAHAAN \\ MANUFAKTUR DI BEI TAHUN 2013-2016
}

\author{
Sustari Alamsyah \\ doni.alamsyah06@gmail.com \\ Universitas Muhammadiyah Tangerang
}

\begin{abstract}
Abstrak
Tujuan penelitian ini untuk menguji dan menganalisis pengaruh faktor internal perusahaan seperti profitabilitas, likuiditas, solvabilitas, arus kas dan pertumbuhan perusahaan terhadap opini audit going concern. Desain penelitian bersifat kausalitas dengan unit analisisnya adalah perusahaan dari sampel yang diambil dengan teknik purposive sampling pada populasi perusahaan manufaktur terdaftar di BEI tahun 2013-2016. Teknik analisis yang digunakan adalah regresi logistik. Hasil penelitian menunjukkan bahwa secara simultan variabel independen berpengaruh terhadap variabel dependen, sedangkan secara parsial variabel solvabilitas dan arus kas berpengaruh terhadap opini audit going concern, dan variabel profitabilitas, likuiditas, dan pertumbuhan perusahaan tidak berpengaruh terhadap opini audit going concern.
\end{abstract}

Kata kunci : Opini Audit Going concern, profitabilitas, solvabilitas, liquiditas, dan arus kas.

Abstract

The purpose of this study is to examine and analyze the influence of internal factors such as profitability, liquidity, solvency, cash flow and corporate growth on going concern audit opinion. The research design is causality with the unit of analysis is the company of the samples taken by purposive sampling technique on the population of manufacturing companies listed on the BEI year 2013-2016. Analytical technique used is logistic. The results showed that simultaneously the independent variables have an effect on the dependent variable, whereas the partial variable of solvency and cash flow have an effect on going concern audit opinion, and profitability, liquidity, and company growth variables have no effect on going concern audit opinion.

Keywords: Audit Opinion Going concern, profitability, solvency, liquidity, and cash flow

\section{PENDAHULUAN}


Kondisi kesulitan keuangan yang dialami perusahaan selain dari faktor eksternal, juga ada yang berasal dari internal perusahaan, misalnya kasus manipulasi laporan keuangan yang dilakukan oleh manajemen perusahaan yang pada akhirnya mengalami kebangkrutan. seperti kasus bangkrutnya perusahaan industri energi Enron merupakan salah satu contoh terjadinya fraud manajemen dan auditor. Selain dimotori oleh manajemen, kegagalan tersebut juga disebabkan hilangnya independensi auditor untuk menilai kemampuan perusahaan dalam mempertahankan kelangsungan usahanya.

Masalah timbul ketika banyak terjadi kesalahan opini (audit failures) yang dibuat oleh auditor menyangkut opini going concern (Sekar, 2003). Opini audit going concern merupakan opini yang dikeluarkan auditor untuk memastikan apakah perusahaan dapat mempertahankan kelangsunagn hidupnya (SPAP, seksi 341, 2001). Atas dasar banyaknya kasus tersebut, maka AICPA (1988) mensyaratkan bahwa auditor harus mengemukakan secara eksplisit apakah perusahaan klien akan dapat mempertahankan kelangsungan hidupnya sampai setahun kemudian setelah pelaporan. Meskipun auditor tidak bertanggung jawab terhadap kelangsungan hidup perusahaan tetapi dalam melakukan audit perlu menjadi pertimbangan auditor dalam memberikan opini. Dengan adanya keraguan perusahaan untuk dapat melakukan kelangsungan usahanya, maka auditor dapat memberikan opini going concern. Kajian atas opini audit going concern dapat dilihat dari kondisi internal perusahaan, yaitu melalui profitabilitas, likuiditas, solvabilitas, arus kas dan pertumbuhan perusahaan, dimana faktor internal tersebut merupakan dasar atau acuan bagi profesional adjugment di dalam memberikan opini audit going concern.

Berdasarkan hasil kajian, analisis, serta penelitian tentang faktor-faktor yang berpengaruh terhadap opini audit going concern, maka motivasi penelitian ini yaitu: pertama, ingin meneliti kembali faktor-faktor yang mempengaruhi opini audit going concern karena masih ditemukanya hasil penelitian yang kontradiktif (research gap) terhadap hasil penelitian terdahulu tentang determinan opini audit going concern. Kedua, masih ditemukannya kesalahan auditor dalam memberikan opini audit going concern (research problem), padahal opini going concern merupakan opini yang diberikan oleh auditor tentang kesangsian auditor terhadap perusahaan dalam mempertahankan kelangsungan hidupnya (IAI, 2001:Seksi 341). Berdasarkan motivasi tersebut, maka penulis tertarik untuk menganalisis tentang " Determinan Opini Audit Going Concern Pada Perusahaan Manufaktur Di BEI Tahun 20132016"

\section{TINJAUAN TEORITIS DAN HIPOTESIS}

\section{Teori Keagenan (Agency Theory)}

Jensen dan Meckling (1976) mendefinisikan hubungan keagenan sebagai suatu kontrak dimana satu orang atau lebih (prinsipal) meminta pihak lainnya (agen) untuk melaksanakan sejumlah pekerjaan atas nama prinsipal yang melibatkan pendelegasian beberapa wewenang pembuatan keputusan kepada agen. Baik 
prinsipal maupun agen sama-sama berusaha untuk maximilisasi utility sehingga memungkinkan mereka melakukan self interest. Auditor sebagai pihak yang independen dibutuhkan untuk melakukan pengawasan terhadap kinerja manajemen apakah telah bertindak sesuai kepentingan prinsipal melalui laporan keuangan.

\section{Opini Audit Going Concern}

Going concern adalah kemampuan entitas dalam mempertahankan kelangsungan hidupnya selama periode waktu pantas, yaitu tidak lebih dari satu tahun sejak tanggal laporan keuangan diterbitkan (SPAP, 2001). Opini audit going concern merupakan opini yang diberikan oleh auditor untuk memastikan apakah perusahaan dapat mempertahankan kelangsungan hidupnya (SPAP, 2001). Berdasarkan SA Seksi 341 paragraf 06, beberapa contoh kondisi atau peristiwa yang bisa menunjukkan adanya kesangsian besar tentang kemampuan entitas dalam mempertahankan kelangsungan hidupnya adalah sebagai berikut:

a. Trend negatif, sebagai contoh kerugian operasi yang berulang kali terjadi, kekurangan modal kerja, arus kas negatif dari kegiatan usaha.

b. Kesulitan keuangan, misalnya kegagalan dalam memenuhi kewajiban utangnya.

c. Masalah intern, misalnya pemogokan kerja atau kesulitan hubungan perburuhan.

d. Pengaduan gugatan pengadilan, keluarnya undang-undang, atau masalah lain yang kemungkinan membahayakan kemampuan perrusahaan untuk beroperasi.

\section{Pengembangan Hipotesis}

\section{Pengaruh Profitabilitas Terhadap Opini Audit Going Concern}

Profitabilitas dalam penelitian ini diproksikan dengan Return On Assets (ROA). Perusahaan yang memiliki nilai ROA negatif menunjukkan bahwa perusahaan mengalami kerugian yang pada akhirnya dapat mengganggu kelangsungan hidup perusahaan. Hal ini sejalan dengan Wati (2013), Sutedja (2010), dan Kristiana (2012) yang menyatakan bahwa profitabilitas berpengaruh negatif terhadap opini audit going concern. Semakin besar rasio ini menunjukkan semakin besar kemampuan perusahaan untuk menghasilkan laba sehingga tidak menimbulkan keraguan auditor akan kemampuan perusahaan untuk melanjutkan usahanya. Berdasarkan uraian tersebut, hipotesis dalam penelitian ini adalah sebagai berikut :

$H_{1}$ : Profitabilitas berpengaruh negatif terhadap opini audit going concern

\section{Pengaruh Likuiditas terhadap Opini Audit Going Concern}

Likuiditas merupakan kemampuan perusahaan untuk membayar kewajiban jangka pendeknya. Likuiditas dalam penelitian ini diproksikan dengan current ratio, yaitu kemampun perusahaan memenuhi kewajiban jangka pendeknya dengan seluruh aset lancar yang dimiliki perusahaan. Semakin tinggi current ratio maka semakin besar pula kemampuan perusahaan untuk memenuhi kewajiban finansial jangka jangka pendek. Penelitian Kristiana (2012) dan Fauziah (2014) menyatakan bahwa likuiditas berpengaruh negatif signifikan terhadap opini audit going concern. Berdasarkan uraian tersebut maka hipotesis dalam penelitian ini adalah sebagai berikut : 
$H_{2}$ : Likuiditas berpengaruh negatif terhadap opini audit going concern.

\section{Pengaruh Solvabilitas terhadap Opini Audit Going Concern}

Menurut Sugiarso (2006), solvabilitas adalah kemampuan perusahaan untuk membayar seluruh hutangnya. Solvabilitas dalam penelitian ini diproksikan dengan Debt to total assets (DAR) yaitu perbandingan jumlah utang dengan total aset. Perusahaan yang bonafit dan dapat mengimbangi seluruh hutang-hutangnya, maka perusahaan tersebut dapat bertahan hidup dalam menjalankan opersinya. Penelitian yang dilakukan oleh Lestari dan Supadmini (2012) menunjukkan bahwa solvabilitas berpengaruh positif terhadap penerimaan opini audit going concern. Berdasarkan uraian tersebut, maka hipotesis yang dapat diajukan dalam penelitian ini adalah:

$H_{3}$ : Solvabilitas berpengaruh positif terhadap opini audit going concern.

\section{Pengaruh Arus Kas terhadap Opini Audit Going Concern}

Dalam PSAK 2 (Rev 2013) dijelaskan bahwa arus kas operasi merupakan arus kas yang berasal dari aktivitas penghasil utama pendapatan entitas yang mencakup aktivitas produksi dan penjualan barang. Jumlah arus kas yang berasal dari aktivitas operasi merupakan indikator yang menentukan apakah dari operasi perusahaan dapat menghasilkan arus kas yang cukup untuk melunasi pinjaman. Masyitoh dan Andhariani (2010) dalam Widyantari (2011) menyatakan bahwa jika perusahaan memiliki kas yang memadai maka perusahaan dapat menghindarkan diri dari kegagalan untuk memenuhi kewajiban dan financial distress sehingga perusahaan diharapkan tidak menerima opini audit going concern. Berdasarkan uraian tersebut, maka hipotesis yang dapat diajukan dalam penelitian ini adalah :

$H_{4}$ : Arus kas berpengaruh negatif terhadap opini audit going concern.

\section{Pengaruh Pertumbuhan Perusahaan terhadap Opini Audit Going Concern}

Pertumbuhan perusahaan mengindikasikan kemampuan perusahaan dalam mempertahankan kelangsungan usahanya. Pertumbuhan perusahaan dapat diproksikan dengan rasio pertumbuhan penjualan. Rasio ini mengukur seberapa baik perusahaan mempertahankan posisi ekonominya, baik dalam industrinya maupun dalam kegiatan ekonomi secara keseluruhan. Penelitian yang dilakukan oleh Arman (2013) menunjukkan bahwa ada hubungan negatif signifikan antara pertumbuhan perusahaan dengan opini audit going concern. Semakin besar nilai pertumbuhan perusahaan maka akan semakin kecil kemungkinannya perusahaan tersebut menerima opini audit going concern. Berdasarkan uraian tersebut, maka hipotesis yang dapat diajukan dalam penelitian ini adalah:

$H_{5}$ : Pertumbuhan perusahaan berpengaruh terhadap opini audit going concern.

\section{Pengaruh Profitabilitas, Likuiditas, Solvabilitas, Arus Kas, dan Pertumbuhan} Perusahaan terhadap Opini Audit Going Concern

Faktor internal perusahaan seperti: profitabilitas, likuiditas, solvabilitas, arus kas dan pertumbuhan perusahaan dianggap sebagai faktor penentu auditor dalam memberikan opini audit going concern. Apabila faktor internal perusahaan tinggi, maka kemungkinan mendapat opini audit going concern dari auditor semakin kecil, 
sebab perusahaan mampu menjalankan kegiatan operasinalnya dengan baik. Berdasarkan uraian ini, maka hipotesis yang diajukan dalam penelitian ini adalah:

$H_{6}$ : Profitabilitas, likuiditas, solvabilitas, arus kas dan pertumbuhan perusahaan secara simultan berpengaruh terhadap opini audit going concern.

\section{METODE PENELITIAN}

\section{Desain Penelitian}

Penelitian ini bersifat kuantitatif, dimana tipe hubungan antar variabel adalah pengaruh kausalitas yaitu variabel independen mempengaruhi variabel dependen. Dalam membuktikan hipotesisnya, penelitian ini menggunakan analisis regresi logistik (logistic regression). Sampel penelitian diambil dengan teknik purposive sampling dengan kriteria :1. Perusahaan manufaktur terdaftar di BEI selama periode berturut-turut 2013-2016; 2. Menerbitkan laporan keuangan secara lengkap dan telah diaudit pada periode yang berakhir 31 Desember; 3. Memiliki laba positif secara berturut-turut selama periode pengamatan; 4. Menerbitkan laporan keuangan dengan mata uang pelaporan berupa rupiah

\section{Devinisi Operasional Dan Pengukuran Variabel Variabel Dependen}

Variabel dependen berupa opini audit going concern, diukur dengan skala dummy, dimana kategori 1 untuk perusahaan yang mendapatkan opini audit going concern dan kategori 0 untuk perusahaan dengan opini audit non going concern.

\section{Variabel Independen \\ Profitabilitas}

Profitabilitas mengukur kemampuan dalam menghasilkan laba maupun nilai ekonomis dari penjualan dengan memanfaatkan aset bersih perusahaan maupun modal sendiri (Raharjaputra, 2009:205). Dalam penelitian ini, profitabilitas diproksikan oleh return on assets (ROA) yang secara matematis dirumuskan yaitu:

$$
(\text { ROA })=\frac{\text { EBIT }}{\text { Total Aset }}
$$

\section{Likuiditas}

Likuiditas merupakan kemampuan suatu perusahaan untuk memenuhi kewajiban finansialnya yang segera harus dipenuhi (Riyanto, 2008:25). Penelitian ini menggunakan rasio lancar (current ratio) yang secara matematis dirumuskan sebagai berikut:

$$
(\mathrm{CR})=\frac{\text { Aset Lancar }}{\text { Liabilitas Jangka Pendek }}
$$

\section{Solvabilitas}

Solvabilitas menunjukkan proporsi atas penggunaan utang untuk membiayai investasinya (Sartono, 2001:120). Solvabilitas dalam penelitian ini menggunakan debt to asset ratio dilakukan dengan tujuan untuk mengukur seberapa besar aset perusahaan dibiayai dengan hutang. Rasio ini bisa dihitung sebagai berikut : 


$$
(\mathrm{DAR})=\frac{\text { Total Liabilitas }}{\text { Total Aset }}
$$

\section{Arus Kas}

Arus kas dalam penelitian ini diukur dengan menggunakan cash flow to total debt ratio (Mills dan Yamamura, 1998). Rasio ini bisa dihitung dengan rumus sebagai berikut:

$$
(\text { CFTDR })=\frac{\text { Arus Kas Operasi }}{\text { Total Liabilitas }}
$$

\section{Pertumbuhan Perusahaan}

Pertumbuhan perusahaan yaitu kenaikan atau penurunan penjualan yang dibandingkan dengan tahun sebelumnya. Pertumbuhan perusahaan diproksikan dengan rasio pertumbuhan penjualan yang secara matematis dirumuskan sebagai berikut (Rahayu, 2012):

$$
(\mathrm{PP})=\frac{\text { Penjualan }_{\mathrm{t}}-\text { Penjualan }_{\mathrm{t}-1}}{\text { Penjualan }_{\mathrm{t}-1}}
$$

\section{Metode Analisis Data}

\section{Analisis Statistik Deskriptif}

Statistik deskriptif memberikan gambaran atau deskripsi suatu data yang dilihat dari nilai rata-rata (mean), standar deviasi, varian, maksimum, minimum, sum, range, kurtosis dan skewness (Ghozali, 2013:19).

\section{Uji Kualitas Data}

\section{Uji Multikolinearitas}

Uji multikolinearitas bertujuan untuk menguji apakah dalam model regresi ditemukan adanya korelasi antar variabel independen. Model regresi yang baik ditunjukkan dengan tidak adanya gejala korelasi yang kuat diantara variabel bebasnya. Pengujian ini menggunakan matrik korelasi antar variabel bebas untuk melihat besarnya korelasi antar variabel independen. Apabila nilai koefisien korelasi antar variabel bebas lebih kecil dari 0,8 berarti tidak terdapat gejala multikolinearitas yang serius antar variabel bebas tersebut.

\section{Menilai Kelayakan Model Regresi}

Kelayakan model regresi dinilai menggunakan Hosmer and Lemeshow's Goodness of Fit Test. Dasar pengambilan keputusan yaitu dengan memperhatikan nilai chi-square pada bagian bawah ini :

1. $\mathrm{H}_{0}$ diterima, jika probabilitas $>0,05$

2. $\mathrm{H}_{0}$ ditolak, jika probabilitas $<0,05$

\section{Menilai Keseluruhan Model}

Menilai keseluruhan model (Overall Model Fit) dengan cara membandingkan angka -2 Log Likelihood (-2LL) pada awal (Block Number =0) dan angka -2 Log Likelihood pada akhir (Block Number $=1$ ). Adanya pengurangan nilai -2LL awal 
(initial -2LL function) dengan nilai 2LL pada langkah berikutnya menunjukkan model yang dihipotesiskan fit dengan data (Ghozali, 2006:232).

\section{Koefisien Determinasi}

Besarnya nilai koefisien determinasi pada model regresi logistik ditunjukkan dengan nilai Nagelkerke $R$ square, dilakukan untuk mengetahui seberapa besar variabel independen mampu mempengaruhi variabel dependen. Nilai Nagelkerke $R$ Square dapat diinterpretasikan seperti nilai $R$ Square pada regresi berganda (Ghozali, 2006:233).

\section{Pengujian Hipotesis \\ Uji Parsial (t-test)}

Uji $t$ atau uji parsial digunakan untuk menguji pengaruh dari tiap-tiap variabel independen terhadap variabel dependen. Uji ini dilakukan dengan membandingkan $t$ hitung dan $\mathrm{t}$ tabel atau dapat juga menggunakan nilai sig. dengan kriteria :

Jika nilai Prob $>\alpha 0,05$, maka $\mathrm{H}_{0}$ diterima yang artinya variabel independen $(\mathrm{X})$ secara parsial tidak berpengarh terhadap variabel dependen (Y). Namun sebaliknya, jika nilai Prob $<\alpha 0,05$, maka Ha diterima..

\section{Analisis Regresi Logistik}

Regresi logistik ini digunakan untuk menguji apakah probabilitas terjadinya variabel terikat dapat diprediksi dengan variabel bebasnya (Ghozali, 2006:120). Pengujian ini dilakukan dengan menggunakan regresi logistik dikarenakan data variabel dependen berupa data kategori. Teknik analisis regresi logistik tidak memerlukan asumsi normalitas data pada variabel bebasnya (Ghozali, 2006:225). Model regresi logistik pada penelitian ini ditunjukkan dalam persamaan berikut :

$\operatorname{Ln} \frac{\mathrm{GC}}{1-\mathrm{GC}}=\alpha+\beta_{1} \mathrm{ROA}+\beta_{2} \mathrm{CR}+\beta_{3} \mathrm{DAR}-\beta_{4} \mathrm{CFDR}-\beta_{5} \mathrm{PP}+\varepsilon$

Keterangan : $\operatorname{Ln} \frac{\mathrm{GC}}{1-\mathrm{GC}}=($ Opini Audit Going Concern $) ; \alpha=$ Konstanta; $\beta=$ Koefisien Regresi; Profitabilitas = ROA; Likuiditas = CR; Solvabilitas = DAR; Arus Kas = CFDTR; Pertumbuhan Perusahaan $=$ PP; $\varepsilon=$ Error.

\section{HASIL DAN PEMBAHASAN \\ Deskripsi Umum Sampel}

Berdasarkan penjelasan teknik pengambilan sampel (purposive sampling), maka jumlah perusahaan yang memenuhi kriteria yang ada di dalam penelitian ini sebanyak 58 perusahaan dengan jumlah data 232 observasi ( $58 \times 4$ tahun).

\section{Hasil Uji Statistik Deskriptif}

Analisis ini untuk menjelaskan nilai maksimum dan minimum, nilai rata-rata (mean) dan nilai standar deviasi. Hal ini dapat ditunjukkan pada tabel di bawah ini:

Statistik Deskriptif

\begin{tabular}{|l|r|r|r|r|r|}
\hline & \multicolumn{1}{|c|}{$\mathbf{N}$} & \multicolumn{1}{c|}{ Min } & \multicolumn{1}{c|}{ Max } & \multicolumn{1}{c|}{ Mean } & \multicolumn{1}{c|}{ Std. Dev } \\
\hline ROA & 232 &, 00003 &, 85390 &, 137807 &, 11661711 \\
CR & 232 &, 3478 & 13,8658 & 2,70272 & 2,2567332 \\
DAR & 232 &, 0499 &, 8809 &, 402088 &, 1796279
\end{tabular}




\begin{tabular}{|l|r|r|r|r|r|} 
Arus_Kas & 232 &,- 6690 & 2,0732 &, 335591 &, 4479956 \\
PP & 232 &,- 2990 & 2,6902 &, 122376 &, 2474982 \\
OGC & 232 & 0 & 1 &, 03 &, 183 \\
Valid N (listwise) & 232 & & & & \\
\hline
\end{tabular}

\section{Hasil Uji Kualitas Data}

\section{Menilai Kelayakan Model Regresi}

Langkah awal untuk mengetahui bahwa suatu model regresi logistik merupakan sebuah model yang tepat, terlebih dahulu akan dilihat bentuk kecocokan atau kelayakan model secara keseluruhan. Dalam hal ini digunakan uji Hosmer and Lemeshow's test.

Hosmer and Lemeshow Test

\begin{tabular}{|l|r|r|r|}
\hline Step & Chi-square & Df & Sig. \\
\hline 1 & 4,854 & &, 773 \\
\hline
\end{tabular}

Sumber : Data diolah peneliti, 2017

Nilai Chi-square adalah 4.854 dengan prob sig. 0,773 yang nilainya jauh di atas 0,05. Sehingga dapat disimpulkan bahwa model dapat diterima karena cocok dengan data observasinya (Ghozali, 2013).

\section{Menilai model Fit (Overall Model Fit Test)}

Adanya pengurangan nilai antara -2LL awal (initial-2LL function) dengan nilai 2LL pada langkah berikutnya menunjukkan bahwa model yang dihipotesiskan fit dengan data. -2 Log Likehood pada regresi logistik mirip dengan pengertian Sum of square Error pada model regresi, sehingga penurunan Log Likehood menujukkan model regresi logistik semakin baik.

Berdasarkan hasil uji -2 Log Likelihood, nilai -2LL awal sebesar 96,797, setelah dimasukkan kelima variabel independen, nilai -2LL akhir mengalami penurunan menjadi sebesar 69,598. Adanya pengurangan tersebut menunjukkan bahwa model penelitian fit dengan data. Artinya penambahan variabel bebas yaitu profitabilitas, likuiditas, solvabilitas, arus kas dan pertumbuhan perusahaan ke dalam model penelitian akan memperbaiki model fit penelitian ini.

\section{Koefesien Determinasi (Nagelkerke R square)}

Koefisien determinasi digunakan untuk mengetahui seberapa besar pengaruh variabel independen terhadap variabel dependen. Hasil koefisien determinasi dapat kita lihat pada tabel dibawah ini :

\section{Model Summary}

\begin{tabular}{|l|r|r|r|}
\hline Step & -2 Log likelihood & $\begin{array}{c}\text { Cox \& Snell R } \\
\text { Square }\end{array}$ & $\begin{array}{c}\text { Nagelkerke R } \\
\text { Square }\end{array}$ \\
\hline 1 & $43,601^{\mathrm{a}}$ &, 106 &, 409 \\
\hline
\end{tabular}

Hasil uji Negelkerke $R$ Square menunjukkan nilai Negelkerke $R$ Square sebesar 0,409 , hal ini berarti variabilitas variabel dependen yang dapat dijelaskan oleh variabel independen adalah sebesar 40,9\%, sedangkan sisanya sebesar 59,1\% dijelaskan oleh variabel-variabel lain di luar model penelitian ini.

\section{Uji Multikolinieritas}


Pengujian ini menggunakan matrik korelasi untuk melihat besarnya korelasi antar variabel independen. Hasil pengujian pada menunjukkan tidak ada nilai koefisien korelasi antar variabel independen yang lebih besar dari 0,8, maka dapat disimpulkan tidak terdapat indikasi multikolinieritas antar variabel independen.

\section{Pengujian Hipotesis}

Pengujian secara parsial digunakan untuk melihat pengaruh masing-masing variabel independen terhadap variabel dependen. Pengujian hipotesis dilakukan dengan cara membandingkan antara tingkat signifikansi (sig) dengan tingkat kesalahan $(\alpha)=5 \%$. Hasil pengujian secara parsial dapat kita lihat pada tabel sebagai berikut:

Hasil Analisis Regresi Logistik

\begin{tabular}{|ll|r|r|r|r|r|r|}
\hline & & \multicolumn{1}{c|}{ B } & S.E. & Wald & df & \multicolumn{1}{c|}{ Sig. } & Exp (B) \\
\hline Step & ROA & $-9,287$ & 9,546 &, 946 & 1 &, 331 &, 000 \\
$1^{\text {a }}$ & CR &,- 861 & 1,150 &, 561 & 1 &, 454 &, 423 \\
& DAR & 8,051 & 3,209 & 6,297 & 1 &, 012 & 3137,425 \\
& Arus_Kas &,- 377 & 3,586 & 2,357 & 1 &, 032 &, 686 \\
& PP & $-3,046$ & 2,883 & 1,116 & 1 &, 291 &, 048 \\
& Constant & $-5,502$ & 2,901 & 3,596 & 1 &, 058 &, 004 \\
\hline
\end{tabular}

Sumber : Data hasil pengolahan, 2017

\section{Pengujian $\mathrm{H}_{1}$ : Pengaruh profitabilitas terhadap opini audit going concern}

Variabel profitabilitas memiliki signifikansi 0,331 yang lebih besar dari $\alpha$ 0,05 . Karena nilai sig $(0,331)>\alpha(0,05)$, maka dapat disimpulkan bahwa hipotesis pertama atau $\mathrm{H}_{1}$ dalam penelitian ini ditolak, yang artinya profitabilitas tidak berpengaruh terhadap opini audit going concern.

\section{Pengujian $\mathrm{H}_{2}$ : Pengaruh likuiditas terhadap opini audit going concern}

Variabel likuiditas memiliki signifikansi 0,454 yang lebih besar dari $\alpha 0,05$. Karena nilai sig $(0,454)>\alpha(0,05)$, maka dapat disimpulkan bahwa hipotesis kedua atau $\mathrm{H}_{2}$ dalam penelitian ini ditolak, yang artinya likuiditas tidak berpengaruh terhadap opini audit going concern.

\section{Pengujian $\mathrm{H}_{3}$ : Pengaruh solvabilitas terhadap opini audit going concern}

Variabel solvabilitas memiliki signifikansi 0,012 yang lebih kecil dari $\alpha 0,05$. Karena nilai sig $(0,012)<\alpha(0,05)$, maka dapat disimpulkan bahwa hipotesis ketiga atau $\mathrm{H}_{3}$ dalam penelitian ini diterima, artinya solvabilitas berpengaruh positif terhadap opini audit going concern.

\section{Pengujian $\mathrm{H}_{4}$ : Pengaruh arus kas terhadap opini audit going concern}

Variabel arus kas memiliki signifikansi 0,032 yang lebih kecil dari $\alpha 0,05$. Karena nilai sig $(0,032)>\alpha(0,05)$, maka dapat disimpulkan bahwa hipotesis keempat atau $\mathrm{H}_{4}$ pada penelitian ini diterima, yang artinya arus kas berpengaruh terhadap opini audit going concern.

Pengujian $\mathrm{H}_{5}$ : Pengaruh pertumbuhan perusahaan terhadap opini audit going concern 
Variabel pertumbuhan perusahaan memiliki signifikansi 0,291 yang lebih besar dari nilai $\alpha 0,05$. Karena nilai sig $(0,291)>\alpha(0,05)$, maka dapat disimpulkan bahwa hipotesis kelima atau $\mathrm{H}_{5}$ pada penelitian ini ditolak, yang artinya pertumbuhan perusahaan tidak berpengaruh terhadap opini audit going concern.

Pengujian $\mathrm{H}_{6}$ : Profitabilitas, likuiditas, solvabilitas, arus kas dan pertumbuhan perusahaan secara simultan berpengaruh terhadap opini audit going concern

Pengujian simultan dilakukan untuk mengetahui apakah variabel independen secara simultan berpengaruh terhadap variabel dependen. Nilai chi-square sebesar 4,854 dengan tingkat pro sebesar 0,773 yang lebih besar dari 0,05, maka dapat dikatakan bahwa profitabilitas, likuiditas, solvabilitas, arus kas dan pertumbuhan perusahaan secara simultan berpengaruh terhadap opini audit going concern.

\section{Analisis Regresi Logistik}

Berdasarkan hasil pengujian yang dapat dilihat pada tabel sebelumnya, maka persamaan regresi logistik dapat dituliskan sebagai berikut:

$\operatorname{Ln} \frac{G C}{1-G C}=-5,502-9,287 R O A-0,861 C R+8,051 D A R-0,377$ Arus Kas $-3,046 P P+\varepsilon$

Dari hasil uji analisis regresi logistik terlihat bahwa konstanta sebesar -5,502 yang menunjukkan adanya pengaruh dari variabel bebas. Apabila nilai dari profitabilitas, likuiditas, solvabilitas, arus kas dan pertumbuhan perusahaan 0, maka opini audit going concern adalah sebesar $-5,502$.

\section{Pembahasan Hasil Penelitian}

\section{Pengaruh Profitabilitas Terhadap Opini Audit Going Concern}

Hasil pengujian hipotesis menunjukkan bahwa profitabilitas tidak berpengaruh terhadap opini audit going concern. Hal ini menunjukkan bahwa auditor dalam memberikan opini tidak melihat tingkat profitabilitas tetapi lebih kepada kemampuan perusahaan dalam menjalankan operasinya, terutama memenuhi kewajiban jangka pendek dan jangka panjangnya. Selama perusahaan mampu memenuhi kewajiban jangka pendek dan jangka panjangnya maka masih mempunyai peluang untuk dapat bekerja lebih efektif dan efisien sehingga mampu bertahan dan meningkatkan labanya. Hasil tersebut sejalan dengan penelitian Rahayu (2012) dan Masyitoh dan Adhariani (2010).

\section{Pengaruh Likuiditas Terhadap Opini Audit Going Concern}

Hasil pengujian hipotesis menunjukkan bahwa likuiditas tidak berpengaruh pada opini audit going concern. Hasil penelitian ini menunjukkan bahwa auditor dalam menerbitkan opini audit going concern tidak hanya mempertimbangkan kemampuan perusahaan untuk memenuhi kewajiban jangka pendeknya, tetapi lebih melihat pada kemampuan perusahaan untuk membayar seluruh kewajibannya. Hal ini dapat dilihat bahwa perusahaan memiliki tingkat likuiditas yang sangat baik. Hasil tersebut tidak mendukung hipotesis kedua dalam penelitian ini. Hasil penelitian ini sejalan dengan penelitian Rahayu (2012) serta Masyitoh dan Adhariani (2010).

\section{Pengaruh Solvabilitas Terhadap Opini Audit Going Concern}


Hal ini menunjukkan bahwa semakin besar debt to asset ratio perusahaan maka akan semakin besar kemungkinan perusahaan untuk menerima opini audit going concern. Solvabilitas yang tinggi akan menyebabkan perusahaan lebih memfokuskan penggunaan modalnya untuk membayar kewajiban daripada untuk mendanai operasi perusahaannya. Hal ini menyebabkan kemampuan perusahaan untuk menjalankan operasionalnya akan berkurang sehingga dapat berpotensi menyebabkan terganggunya kelangsungan hidup perusahaan. Rasio solvailitas yang tinggi juga menunjukkan semakin kecil aktiva perusahaan yang didanai oleh pemilik sehingga risiko perusahaan berupa cost of capital juga akan semakin besar. Hal ini dapat menimbulkan kesangsian auditor akan kemampuan perusahaan untuk menjalankan usahanya dimasa yang akan datang. Hasil pengujian hipotesis menunjukkan bahwa solvabilitas berpengaruh positif pada opini audit going concern. Hasil tersebut mendukung hipotesis ketiga dalam penelitian ini.

\section{Pengaruh Arus Kas Terhadap Opini Audit Going Concern}

Informasi tentang arus kas suatu perusahaan berguna bagi para pengguna laporan keuangan sebagai dasar yang memadai untuk menilai kemampuan perusahaan dalam menghasilkan kas serta setara kas dan menilai kebutuhan perusahaan untuk menggunakan arus kas tersebut. Hasil pengujian menunjukkan bahwa arus kas berpengaruh terhadap opini audit going concern. Hasil tersebut mendukung hipotesis keempat dalam penelitian ini. Hal ini menunjukkan bahwa auditor dalam memberikan opini audit going concern berdasarkan pada kemampuan perusahaan untuk melakukan kegiatan operasinya terhadap total hutang yang ada di perusahaan, jika arus kas yang dimiliki oleh perusahaan memadai, maka kemungkinan perusahaan untuk menjalankan operasinya tidak akan terganggu. Hasil penelitian ini konsisten dengan temuan penelitian Masyitoh dan Adhariani (2010)

\section{Pengaruh Pertumbuhan Perusahaan Terhadap Opini Audit Going Concern}

Hasil pengujian hipotesis menunjukkan bahwa pertumbuhan perusahaan tidak berpengaruh pada opini audit going concern. Hasil tersebut tidak mendukung hipotesis kelima dalam penelitian ini. Pertumbuhan perusahaan yang diproksikan dengan pertumbuhan penjualan tidak selalu mengindikasikan bahwa laba yang diperoleh perusahaan juga meningkat. Peningkatan beban operasional yang lebih tinggi dibandingkan peningkatan penjualan akan mengakibatkan laba bersih yang negatif dan berdampak pada saldo laba ditahan perusahaan. Hasil penelitian ini menunjukkan bahwa auditor tidak mempertimbangkan pertumbuhan penjualan perusahaan dalam memberikan opini audit going concern karena peningkatan penjualan tersebut belum tentu diikuti dengan kemampuan perusahaan dalam menjalankan kegiatan operasinya. Hasil penelitian tersebut sejalan dengan temuan penelitian Fanny dan Saputra (2005) serta Setyarno dkk. (2006).

\section{KESIMPULAN, KETERBATASAN DAN SARAN KESIMPULAN}


Berdasarkan analisis data dan pembahasan yang telah dilakukan maka dapat diambil suatu kesimpulan sebagai berikut :

1. Profitabilitas tidak berpengaruh terhadap opini audit going concern

2. Likuiditas tidak berpengaruh terhadap opini audit going concern

3. Solvabilitas berpengaruh terhadap opini audit going concern

4. Arus kas berpengaruh terhadap opini audit going concern

5. Pertumbuhan perusahaan tidak berpengaruh terhadap opini audit going concern

\section{KETERBATASAN}

Terdapat beberapa keterbatasan dalam penelitian antara lain: (1) Sampel perusahaan yang digunakan kurang mewakili seluruh populasi perusahaan yang ada di Indonesia; (2) Penelitian ini hanya menggunakan variabel independen dari faktor internal perusahaan, sedangkan faktor eksternal seperti perubahan kurs, kenaikan tingkat suku bunga dan lain-lain tidak dimasukkan; (3) Periode pengamatan dalam penelitian ini hanya 4 tahun sehingga belum cukup lama untuk melihat trend penerbitan opini audit going concern oleh auditor.

\section{REKOMENDASI}

Berdasarkan keterbatasan dari penelitian ini, peneliti memberikan saran antara lain. Bagi penelitian selanjunya sebaiknya menambah jumlah tahun pengamatan, sehingga dapat melihat trend opini audit oleh auditor dalam jangka panjang, dan dapat juga menggunaan sampel perusahaan lain selain perusahaan manufaktur atau jika memungkinkan melakukan pengujian pada seluruh perusahaan yang terdaftar di Bursa Efek Indonesia. Mengganti dengan variabel lain yang secara teoritis mungkin dapat mepengaruhi opini audit going concern misalnya : kualitas audit, mekanisme Corporate Governance, opinion shopping, dan penerapan strategi manajemen.

\section{DAFTAR PUSTAKA}

Agustina, Triyana Arni dan Zulaikha. 2013. Faktor-Faktor yang Mempengaruhi Keputusan Opini Going Concern Auditor pada Perusahaan Manufaktur yang Terdaftar di Bursa Efek Indonesia (BEI). Diponegoro Journal of Accounting Vol.2 No.1 hal.1-14.

Arman, Endra U. 2013. Pengaruh Profitabilitas, Likuiditas dan Pertumbuhan Perusahaan terhadap Opini Audit Going Concern (Studi Empiris pada Perusahaan Manufaktur yang Terdaftar di Bursa Efek Indonesia. Jurnal Akuntasi Vol. 1 No.3.

Ghozali, Imam. 2013. Aplikasi Analisis Multivariate dengan Program IBM SPSS 21. Semarang: Badan Penerbit Universitas Diponegoro.

Jensen, M., and W.H. Meckling, 1976, The Theory of the Firm: Managerial Behavior, Agency Cost, and Ownership Sructure, Journal of financial Economic 3, No. 4. pg. 305-360.

Kieso, D. E., J. J. Weygandt, dan T. D. Warfield. 2007. Akuntansi Intermediate. Jilid 1. Edisi Keduabelas. Erlangga. Jakarta.

Kristiana, I. 2012. Pengaruh Ukuran Perusahaan, Profitabilitas, Likuiditas, Pertumbuhan Perusahaan terhadap Opini Audit Going Concern pada 
Perusahaan Manufaktur yang Terdaftar di Bursa Efek Indonesia (BEI). Jurnal Berkala Ilmiah Mahasiswa Akuntansi 1 (1): 47-51.

Lestari, Eva dan Supadmini, Sri. 2012. Analisis Pengaruh Profitabilitas, Likuiditas, Solvabilitas, Kualitas Auditor dan Opini Audit Tahun Sebelumnya terhadap Opini Audit Going Concern. Jurnal Ekonomi dan Kewirausahaan Vol.8 No.17.

Rahayu, Santi. 2012. Moderasi Reputasi Auditor Terhadap Faktor-Faktor yang Mempengaruhi Auditor Switching Pada Perusahaan Industri Manufaktur yang Terdaftar di BEI pada Tahun 2006-2010. Tesis. Jakarta: Universitas Esa Unggul.

Santosa, Arga Fajar dan Wedari, Linda K. 2007. Analisis Faktor-Faktor yang Mempengaruhi Kecenderungan Penerimaan Opini Audit Going Concern. JAAI Vol. 11 No.2 hal.141-158.

Sartono, R. Agus. 2001. Manajemen Keuangan Teori dan Aplikasi. Edisi 4.BPFE. Yogykarta.

Widyantari, Putri A.A.Ayu. 2011. Opini Audit Going Concern dacn Faktor yang Mempengaruhi: Studi pada Perusahaan Manufaktur di Bursa Efek Indonesia. Tesis. Denpasar: Universitas Udayana.

IAPI. 2001. Standar Profesi Akuntan Publik. Salemba Empat, Jakarta. 